\title{
Gender Differences in Sexual Dysfunction of Patients with Schizophrenia
}

\author{
Jaafar Nakhli*, Yousri El kissi, Amel Braham, Ahlem Mtiraoui, Bochra Nourhene Saguem, Selma Ben Nasr \\ Psychiatric department, Farhat Hached university hospital, Sousse, Tunisia
}

*Corresponding author: Jaafar Nakhli, Department of Plastic Surgery Jawaharlal Institute of Postgraduate Medical Education and Research (JIPMER) Pondicherry India-605006.

Received date: December 26, 2019; Accepted date: January 18, 2020; Published date: January 27,2020

Citation: Nakhli J, Yousri E. kissi., Braham A., Mtiraoui A., Bochra N. Saguem., Selma B Nasr. (2020) Gender Differences in Sexual Dysfunction of Patients with Schizophrenia. J. Archives of Medical Case Reports and Case Study. 3(1); DOI:10.31579/2692-9392/009

Copyright: (C) 2020 Jaafar Nakhli, This is an open access article distributed under the Creative Commons Attribution License, which permits unrestricted use, distribution, and reproduction in any medium, provided the original work is properly cited.

\begin{abstract}
:
The prevalence of sexual dysfunction in patients with schizophrenia ranged from 50 to $85 \%$. One hundred outpatients with schizophrenia had participated in this study. All these patients had remission criteria. We used sociodemographic and clinical characteristics from medical files and we passed to our patients PANSS and ASEX. Comparison was between female and male groups. Sexual dysfunction was present in 55\% of patients with schizophrenia. Women had higher total ASEX score than men especially in Arousal disorders and orgasm. There was a relationship between the ASEX total score and dose of treatment and with the severity of symptoms.
\end{abstract}

Key Words: sexual dysfunction; Schizophrenia

\section{Background:}

Schizophrenia is a chronic and disabling mental illness of the young. It has a pronounced impact on the sexual abilities of patients. In the literature, the prevalence of sexual dysfunction in these patients ranged from 50 to $85 \%$ [1-3]. Many factors can explain this high prevalence such as hyperprolactinemia, sedation and antagonism of neurotransmitter receptors induced by antipsychotic drugs $[4,5]$.

These sexual dysfunctions can affect their quality of life, self-esteem, attitude toward taking medication and compliance during therapy [5].

Detecting and treating this problem could improve the course and the quality of life of patients with schizophrenia.

This study aimed to assess the prevalence of sexual dysfunction in patients with schizophrenia and to investigate associated gender factors.

\section{Methods}

This study was approved by the ethics committee of the Faculty of Medicine in Sousse. We have performed this study with one hundred first outpatients with a diagnosis of schizophrenia (DSM-IV TR criteria) from the outpatient psychiatric service of Farhat Hached Hospital in Sousse. All these patients met remission criteria of "The Remission in schizophrenia Working Group" with Positive and Negative Syndrome Scale score $<90$ and without any admission in psychiatry since the past 6 months [6].

We administered to our patients a record exploring the sociodemographic and clinical characteristics, the Positive and Negative Syndrome Scale (PANSS) [7] and Arizona Sexual Experience
Scale (ASEX) to assess sexual dysfunction. ASEX scale was translated and validated into Arabic language [8]. Arabic version of ASEX had good internal consistency $(\alpha=0.82)$ and excellent reliability $(r=0.92$, $\mathrm{p}<10(-3)[8]$.

The ASEX scale is commonly used to evaluate sexual dysfunction scales in patients with mental disorders. It's a five-item rating scale that quantifies sex drive, arousal, vaginal lubrication/penile erection, ability to reach orgasm, and satisfaction from orgasm. Possible total scores range from 5 to 30 , with the higher scores indicating more sexual dysfunction. The patient has sexual dysfunction when the ASEX total scores $\geq 19$ or has an item with a score $\geq 5$ or 3 items with a score $\geq 4[8,9]$.

\section{Results}

The mean age of our sample was $37.6 \pm 10.2$ years. $70 \%$ were male, $57 \%$ were single and $73 \%$ were unemployed.

The mean age of onset illness was $24.8 \pm 6.1$ years. Undifferentiated schizophrenia subtype was the most prevalent (58\%). The mean PANSS score was $51.8 \pm 12.8$.

$43 \%$ of this patient has received second generation antipsychotics and the average of Chlorpromazine equivalent dose was $279 \pm 475$ $\mathrm{mg} /$ day.

The mean ASEX total score was $17.7 \pm 5.6$. Sexual dysfunction was present in $55 \%$ of patients with schizophrenia (total score $\geq 19$ or ASEX Item $\geq 5$ or $\geq 3$ items with a score $\geq 4$ ).

The two gender groups was comparable regarding age, age of onset, years of onset of schizophrenia, the mean PANSS score and dose of treatment. 
Women had higher total ASEX score than men $(20.8 \pm 5.9$ vs $16.6 \pm 5$; $\mathrm{p}=0.002$ ). Scores of arousal disorders, vaginal lubrication, orgasm and sexual satisfaction were higher in women than men ( $p$ respectively was $0.005,0.005,0.001$ and 0.017 ) (table I).

\begin{tabular}{|l|c|c|c|}
\hline & Men & Women & p \\
\hline ASEX 1: Sex drive & $3.77 \pm 1.14$ & $4.23 \pm 1.19$ & 0.071 \\
\hline ASEX 2: Arousal & $3.39 \pm 1.06$ & $4.1 \pm 1.26$ & $\mathbf{0 . 0 0 5}$ \\
\hline $\begin{array}{l}\text { ASEX3: Penile erection/ Vaginal } \\
\text { lubrication }\end{array}$ & $3.46 \pm 1.21$ & $4.23 \pm 1.33$ & $\mathbf{0 . 0 0 5}$ \\
\hline ASEX4: Ability to reach orgasm & $3.29 \pm 1.2$ & $4.32 \pm 1.32$ & $\mathbf{0 . 0 0 1}$ \\
\hline ASEX5: Satisfaction from orgasm & $3.27 \pm 1.2$ & $4.05 \pm 1.46$ & $\mathbf{0 . 0 1 7}$ \\
\hline ASEX total score & $16.63 \pm 5.06$ & $20.82 \pm 5.96$ & $\mathbf{0 . 0 0 2}$ \\
\hline
\end{tabular}

Table I: Sexual dysfunction between men and women

There was a relationship between the ASEX total score and dose of treatment $(r=0.36, p=0.001)$ and with the severity of symptoms ( $r$ $=0.31, \mathrm{p}=0.005$ ).

\section{Discussion}

The prevalence of sexual dysfunction in patients with schizophrenia in our study was $55 \%$. This result was similar to the literature with prevalence between 30 to $80 \%[1-3,8]$. In a tunisian sample, Ben Mahmoud and al. found a frequency of 93\% [9]. Many studies have shown that the sexuality of patients with schizophrenia is more impaired than general population $[1-3,10,11]$.

In China's study using ASEX in patients with schizophrenia, sexual dysfunction was found in $61.9 \%$ of men's and $79.2 \%$ in women's [12]. The high rates and gender differences we observed are consistent with other studies $[13,14]$. According to Harley et al., women with schizophrenia experienced more problems in desire and men were more likely to report problems in arousal [15].

Ben Mahmoud had found a decrease in desire and arousal in women with schizophrenia [11]. Miclutia pointed the importance of the relational component, sentimental and emotional sexuality in women compared to men [16].

In Fujii's study, the most sexual dysfunctions in men were sexual desire, erectile dysfunction and ejaculation problem. It was sexual desire in women [17].

Literature data states that all sexual dysfunction can be observed in schizophrenia. They can be attributed to many factors such as the disease [18], the precarious social situation of patients, and the adverse effects of prescribed antipsychotic medications [1,19].

In our study, we found correlation between the severity of symptoms, particularly negative symptoms, and the severity of sexual dysfunction. It has been observed in many studies that cognitive deficit in schizophrenia predicts a progressive deterioration of sexual function $[2,3,20]$.

For the relationship found between sexual disorders and antipsychotic daily intake, Devraux reported no difference between first and second generation antipsychotics [21]. Many studies have found a relationship between blocking D2 receptor, desire and orgasm. In the same way, hyperprolactinemia and low plasma testosterone causes lower desire and erectile dysfunction [15,22,23]. Variety of mechanisms are likely to contribute to antipsychoticrelated sexual dysfunction, including hyperprolactinemia, sedation, and antagonism of a number of neurotransmitter receptors $(\alpha-$ adrenergic, dopaminergic, histaminic and muscarinic) [4,5,23]. Hyperprolactinemia is a major cause of sexual dysfunction. Based on the blockade of dopamine D2 receptors, haloperidol, risperidone, and amisulpride are classed as prolactin-elevating antipsychotics, while olanzapine, clozapine, quetiapine, ziprasidone, and aripiprazole are classed as prolactin-sparing drugs $[4,5]$.

\section{Conclusion}

Sexual dysfunction is prevalent among schizophrenia patients especially among women. This problem seems to be affected from both the disease and its treatment. The high prevalence and the interference with quality of life combine to make sexual dysfunction an important area for clinical assessment and appropriate intervention in the community management of schizophrenia.

\section{No conflict of interest}

\section{References}

1- Dossenbach M, Hodge A, Anders M, et al. (2005) Prevalence of sexual dysfunction in patients with schizophrenia: international variation and underestimation. Int $\mathrm{J}$ Neuropsychopharmacol 8(2):195-201.

2- Fortier P, Mottard JP, Trudel G, et al. (2003) Study of sexuality-related characteristics in young adults with schizophrenia treated with novel neuroleptics and in a comparison group of young adults. Schizophr Bull 29(3):559-572.

3- Montejo AL, Majadas S, Rico-Villademoros F. (2010) Frequency of sexual dysfunction in patients with a psychotic disorder receiving antipsychotics. J Sex Med. 7(10):3404-3413.

4- Park YW, Kim Y, Lee JH. (2012) Antipsychotic-induced sexual dysfunction and its management. World J Mens Health 30(3): 153-159. 
5- Just MJ. (2015) The influence of atypical antipsychotic drugs on sexual function. Neuropsychiatr Dis Treat, 11: 16551661.

6- Andreasen NC, Carpenter WT, Kane JM, Lasser RA, Marder SR, Weinberger DR. (2005) Remission in schizophrenia: proposed criteria and rationale for consensus. Am J Psychiatry, 162(3): 441-449.

7- Kay SR, Flszbein A, Opfer LA. (1987) The positive and negative syndrome scale (PANSS) for schizophrenia. Schizophrenia bulletin 13(2), 261.

8- Nakhli J, El Kissi Y, Bouhlel S, Amamou B, Nabli TA, Nasr SB, Ali BB. (2014) Reliability and validity of the Arizona Sexual Experiences Scale-Arabic version in Tunisian patients with schizophrenia. Compr Psychiatry, 55(6): 1473-1477.

9- Rizvi SJ, Yeung NW, Kennedy SH. (2011) Instruments to measure sexual dysfunction in community and psychiatric populations. J Psychos Res 70(1) : 99-109.

10- Baggaley M. (2008) Sexual dysfunction in schizophrenia: focus on recent evidence. Hum Psychopharmacol, 23(3):201-209.

11- Ben Mahmoud S, Zouari L, Dammak M. (2013) Évaluation de la sexualité d'une série de 61 sujets atteints de psychose chronique. Sexologies, 22: 90-96.

12- Byerly MJ, Nakonezny PA, Fisher R, Magouirk B, Rush AJ. (2006) An empirical evaluation of the Arizona Sexual Experience Scale and a sample one-item screening test for assessing antipsychotic-related sexual dysfunction in outpatients with schizophrenia and schizoaffective disorder. Schizo Resphr, 81(2-3):311-316.

13- Smith S, O'Keane V, Murray R. (2002) Sexual dysfunction in patients taking conventional anti-psychotic medication. $\mathrm{Br}$ J Psychiatry, 181:49-55

14- Macdonald S, Halliday J, MacEwan T, Sharkey V, Farrington S, Wall S, McCreadie RG. (2003) Nithsdale Schizophrenia
Surveys 24: sexual dysfunction. Case-control study. Br J Psychiatry 182(1), 50-56.

15- Harley EW, Boardman J, Craig T. (2010) Sexual problems in schizophrenia: prevalence and characteristics. A cross sectional survey. Soc Psychiatry Psychiatr Epidemiol 45(7), 759-766.

16- Miclutia IV, Popescu CA, Macrea RS. (2008) Sexual dysfunctions of chronic schizophrenic female patients. Sex Relations Ther 23(2):119-129

17- Fujii A, Yasui-Furukori N, Sugawara N et al., (2010) Sexual dysfunction in Japanese patients with schizophrenia treated with antipsychotics. Prog Neuropsychopharmacol Biol Psychiatry 34(2):288-293.

18- Aizenberg D, Zemishlany Z, Dorfman-Etrog P, et al. (1995) Sexual dysfunction in male schizophrenic patients. J Clin Psychiatry 56(4):137-141.

19- Kelly DL, Conley RR. (2006) A randomized double-blind 12week study of quetiapine, risperidone or fluphenazine on sexual functioning in people with schizophrenia. Psychoneuroendocrinology 31(3):340-346.

20- Raja M, Azzoni A. (2003) Sexual behavior and sexual problems among patients with severe chronic psychoses. Eur Psychiatry, 18(2):70-76

21- Devraux A, El Omari F. (2005) Sexual dysfunction in schizophrenics patients, the role of antipsychotics. Presse Med 34(7): 529-532

22- Lachtar C, Bellaaj-Lachtar F, Jarraya A. (2006) Désir sexuel au sein du couple conjugal tunisien. Caractéristiques et facteurs de maintien. Ann Med Psychol, 164:402-409

23- Tardieu S, Micallef J, Bonierbale M, Frauger E, Lancon C, Blin 0. (2006) Comportements sexuels chez le patient schizophrène : impact des antipsychotiques. L'Encéphale 32(cahier 1) : 697-704
This work is licensed under Creative Commons Attribution 4.0 License

To Submit Your Article Click Here: Submit Article

DOI:10.31579/2692-9392/009
Ready to submit your research? Choose Auctores and benefit from:

$$
\begin{aligned}
& \text { * fast, convenient online submission } \\
& \text { *igorous peer review by experienced research in your field } \\
& \text { * rapid publication on acceptance } \\
& \text { * uuthors retain copyrights } \\
& \text { * imique DOI for all articles } \\
& \text { immediate, unrestricted online access }
\end{aligned}
$$

At Auctores, research is always in progress.

Learn more https://www.auctoresonline.org/journals/archives-ofmedical-case-reports-and-case-study 